\section{Olena Vynogradova, Nadiia Pysar, Nina Drokina, Olga Lytvynova, Iryna Sovershenna}

\title{
CRITICAL EVALUATION OF THE SUSTAINABILE DEVELOPMENT PRINCIPLES WITHIN THE FASHION BUSINESS MODEL COMPONENTS FOR EARIY-STAGE COMPANY
}

The object of research is the processes of interaction of business model components for the enterprise in the fashion industry at an early stage of its life cycle, which are subject to the principles of sustainable development and distinguish the business model from the model of «fast fashion». One of the most problematic places is to determine the actual components of the business model of the enterprise of the fashion industry, working on the principles of sustainable development, rather than those that are only declared by the company itself. And also used as a tool for promotion without the actual implementation of these tools. In addition, it is important not only to establish a minimum list of such tools, but also to establish their relationship.

The study used methods of detailed analysis of the current state of the problem, based on information retrieval with extensive use of computers. Methods of empirical research (observation, comparison), method of synthesis and structural-genetic method (extraction from the complex phenomenon of such elements which considerably influence other parties of object of research, in a investigated case of tools of sustainable development) were also used. Various sources of information, databases EBSCO, ResearchGate, Jstor, secondary sources of information, company websites, analytical reports were used. As well as primary sources - interviews with representatives of fashion industry companies that implement «sustainable» practices in business processes at their enterprises (for example, Ze Kout LLC, Kyiv, Ukraine).

The scientific and practical value of the study is that the business activities of modern companies must be consistent with the goals of sustainable development stated by the UN. And development - to involve its consumers not only in the promotion, evaluation or promotion of existing products, but also in the creation of quality products based on the principles of sustainable development. This provides an opportunity to renew the cooperation of companies, update the mission, goals, and vision of business development at high quality standards of sustainable economic development. This allows to reasonably approach the construction of business on the principles of sustainable development and obtain economic effects from the introduction into production of the principles of sustainable development. In particular, product quality can be improved.

Keywords: fashion industry, sustainable development principles, business model, business life cycle, sustainable development.

\section{How to cite}

Vynogradova, O., Pysar, N., Drokina, N., Lytoynova, O., Sovershenna, I. (2021). Critical evaluation of the sustainabile development principles within the fashion business model components for early-stage company. Technology Audit and Production Reserves, 3 (4 (59)), 12-17. doi: http://doi.org/10.15587/ 2706-5448.2021.235625

\section{Introduction}

In recent years, designers have massively reshaped the fashion industry adopting more sustainable business models. Representatives of the public have severely criticized the dominating concept of fast fashion for its promotion of throwaway culture and consumerism. New concepts such as lowsumerism, product longevity, sharing economy and slow fashion are constantly evolving in an attempt to decrease the existing problems. To address the sustainability issues and hopefully help to solve them, the vast majority of fashion designers and brands have developed collections and product lines using renewable or sustainable materials. What is more, brands are extensively «going green» changing their marketing strategy and claiming that they would like to make a difference in making fashion more sustainable. 
However, there is still a discrepancy between what brands claim and what they practice in reality.

Based on the assumptions in many articles, the sustainability in fashion business model is considered as environmental responsibilities and codes of conduct inclusions [1]. Clear focus on circularity in the production process is made by some authors [2]. Authors of [2] highlighted that even the brand's priorities is changing the business models from linear to circular, in order to focus on sustainability, they need to focus on a specific driver within business model.

The industry controls the clothing life-cycle where relatively new garments are thrown away, not because they are worn out, but because they become out of fashion due to the industry marketing strategies [3].

Authors of [4] point out on a necessity to cope with a unsustainable issues within the supply chain.

Paper seeks to analyze key aspects of sustainability elements within business models in the fashion industry. Currently, there is limited information on compulsory minimal bundle of sustainable components within business model, which should indicate for potential customers that company indeed has the sustainable business model. This helps to compile a portrait of sustainable business model for distinguishing the «real» sustainable brands from disguised. The sustainable business model canvas is provided as a result of empirical research; characteristics of the sustainable business model are specified in the research.

That's why the interaction processes of the business model components for the early-stage fashion business is a research subject, it helps to distinguish the sustainable business model from the model of «fast fashion».

The object of research is the processes of interaction of business model components for an enterprise in the fashion industry at an early stage of its life cycle, which are subject to the principles of sustainable development and distinguish the business model from the model of «fast fashion». The aim of research is to find out whether the business model of early companies, such as the Pangaia brand, met the sustainability requirements or not.

\section{Methods of research}

The sustainability of the Pangaia's fashion business model was defined using the data from secondary sources. Different sources have been used including case studies reports, articles, books, databases EBSCO, ResearchGate, Jstor, companies websites, analytical reports. Primary sources interviews with representatives of fashion industry companies that implement «sustainable» practices in business processes at their enterprises (for example, The Coat LLC, Kyiv, Ukraine). While carrying out the research on the websites, reliable opinions about the brands strategy and values have been taken into account. To achieve unbiased and well-grounded results the company's philosophy has been investigated, which is undoubtedly needed to answer the research question: Does the Fashion Business Model of the Brand Pangaia comply with the sustainability requirements? How looks the sustainable business model components bundle? The study used methods of detailed analysis of the current state of the problem, based on information retrieval with extensive use of computers; methods of empirical research (observation, comparison), synthesis and structuralgenetic method (extraction from the complex phenomenon of such elements that significantly affect the other aspects of the object of study, in our case, the tools of sustainable development).

The qualitative analysis of the brand is impossible without studying the whole concept of a fashion business model, as well as the idea of sustainability. Trying to answer the question posed in the research taking into account the broader perspective allows to see the whole picture more clearly and gives a better understanding of the uniqueness of the company.

The research is based on the several theories and concepts. Firstly, the concept of the business model is analyzed and explained. Then, the components of the most popular models will be listed. This links Pangaia to the other brands showing the uniqueness of Pangaia. Further, the existing business models will be studied in terms of their sustainability and impact on the environment.

\section{Research results and discussion}

3.1. Fashion business models and their main components. In recent years, the term business model has gained a lot of popularity. Companies develop new ways of managing their activity. It is widely accepted the company's success depends on the appropriately chosen business model a lot [5]. Thus, studying and analyzing existing business models is an essential step of developing your own unique model of business management.

The concept of a business model has a long history and both its origin and development are associated with business informatics in the mid-1970s and information technology in general.

Business model is a term which can be defined in many different ways as its perception greatly depends on the type of the organization. This variety results in having no single definition of this term, the first of them appearing at the end of the 1990s. Michael Lewis, the financial journalist, introduced this term predicting that business models used by the companies «in the future would be based on business models connected only with the Internet» [1].

Firstly, several terms were often used synonymously: business model, business idea, business concept, revenue model, or economic model. These days the terms business model and business strategy still remain difficult to differentiate [5].

Authors of [6] give an overview of knowledge about the business model and provide the most comprehensive definitions of this term: «the business model is a system of resources and activities, which create a value that is useful to the customer and the sale of this value makes money for the company». Analysis of articles let to make a definition's list of a «business model» term in Table 1.

Different companies have a different understanding of a business model as «the business model is a conceptual tool that includes a set of components and their relationships, presenting a schematic business idea for a specific company» [15]. So, «every company has a business model, whether it is deliberately defined and clearly articulated, or shaped by itself over the course of time» [16].

As for the components and elements of business models, the views and approaches also vary greatly. Each company has a different method or a process for its business model, but there are elements pertaining to all of them: people, strategy, structure, process, and reward [1]. The first element comprises people in the organization and how they and their skills, mindset and culture «must merge with the organization's core strategies». Strategy is associated 
with the companies' performance and competitive position. The third element, which is structure, discusses what type of structure is needed for the successful operation of the business model. The fourth element, process, «outlines the design, implementation, and the business model's evolution». Reward element deals with inspiration and encouragement of the management and employees.

Definitions of a «business model» term

Table 1

\begin{tabular}{|c|c|c|}
\hline Reference & Year & Definition \\
\hline [7] & 2000 & $\begin{array}{l}\text { «The logic of the organization's core for value creation. } \\
\text { The BM of a Profit-oriented organization explains how } \\
\text { it makes money" }\end{array}$ \\
\hline [8] & 2001 & $\begin{array}{l}\text { "A description of the roles and relationships between } \\
\text { consumers, customers, pairs, and suppliers to identify } \\
\text { a major product flow of information and money, and } \\
\text { benefits for the participants" }\end{array}$ \\
\hline [9] & 2003 & $\begin{array}{l}\text { "Term generally used to describe the key components } \\
\text { of a business: customers, competitors, supply, organi- } \\
\text { zation activities, resources, supply and import of the } \\
\text { production, as well as components of the longitudinal } \\
\text { process to cover the BM dynamics over time" }\end{array}$ \\
\hline [10] & 2005 & $\begin{array}{l}\text { "A business model is a conceptual tool containing } \\
\text { a set of objects, concepts and their relationships with the } \\
\text { objective to express the business logic of a specific firm" }\end{array}$ \\
\hline [11] & 2008 & $\begin{array}{l}\text { «Consists of four interlocking elements: customer value } \\
\text { proposition, profit formula, key resources - assets and } \\
\text { key processes» }\end{array}$ \\
\hline [12] & 2010 & $\begin{array}{l}\text { "In the most basic sense, a business model is the } \\
\text { method of doing business by which a company can } \\
\text { sustain itself - that is, generate revenue. The business } \\
\text { model spells-out how a company makes money by } \\
\text { specifying where it is positioned in the value chain" }\end{array}$ \\
\hline [13] & 2012 & $\begin{array}{l}\text { "Consistency between the strategic choices of the com- } \\
\text { pany that enables relationships for creating value at } \\
\text { operational, tactical and strategic levels» }\end{array}$ \\
\hline [14] & 2015 & $\begin{array}{l}\text { «"Details how the firm conducts its business with its } \\
\text { buyers, suppliers, and partners» }\end{array}$ \\
\hline
\end{tabular}

Authors give a scheme illustrating four pillars and ninebuilding blocks for business models developed by Osterwalder, Pigneur, and Tucci [1]. The pillars are infrastructure management, customer interface, product, financial aspects. The system of pillars and building blocks together with the description should be tailored to the needs of every company depending on the business type, their financial aspects and infrastructure management.

3.2. Integrating sustainability practices into fashion business models. The development of a successful business model requires constant adaptation to the changing conditions of the market, thus giving the opportunity for the company to remain competitive on the market. The business model must be developed in the way that accentuates the company's strengths and mitigates the weaknesses. To keep up with the times, companies should track innovations and trends both in the area of business management as a whole and within the specific industry as well.

Undeniably, the production of clothes has a negative impact on the environment. Due to this, there have been numerous attempts to minimize this impact by changing the business models within the whole fashion industry. The key component of these models is the focus on sustainability, achieving which is undoubtedly a long and challenging process.
The sustainable business model can be defined «as supporting voluntary, or mainly voluntary, activities which solve or moderate social and/or environmental problems. By doing so, it creates positive business effects which can be measured or at least argued for. A business model for sustainability is actively managed in order to create customer and social value by integrating social, environmental, and business activities» [17].

A few authors claims that sustainable business model innovation thus focuses on identifying solutions that allow firms to capture economic value, while generating environmental and social value, and in doing so establishing an internal business case for sustainability [2].

Business Sustainability Typology includes four types which can be seen in Fig 1 .

This paper focuses on Business Sustainability 3.0 as it is the most comprehensive type. Business Sustainability 3.0 is an approach to sustainability where a company not only aims to minimize the negative impact of their business activities. When using the Business Sustainability 3.0 approach a business also gains an understanding of how to create a meaningful positive impact in areas that are important to the society and the planet. A Business Sustainability 3.0 company turns the sustainability challenges it faces in its environment into business opportunities. By doing so, the Business Sustainability 3.0 company creates value for the common good in its environment.

Moreover, compared to the other two levels of Business Sustainability, the 3.0 level takes an outside-in organizational perspective, meaning that instead of focusing on the business itself, the focus is on the society and its sustainability challenges. Business Sustainability 3.0 is also referred to as «true sustainable».

The main sustainable criteria picked up for fashion apparel company are the next [18]:

- implementing two or more of the Sustainable Development Goals (SDG's) $(6,11,13,14,15)$ [18, 19]; - usage of sustainable fabriques or other sustainable parts of apparel;

- implementing the Sustainable International certification programmes or Eco-Quality standards (such as: Have been certified with ISO 14001\&9001; Global Organic Textile Standard; Global Recycle Standard; Forest Stewardship Council; Organic Content Standard 100); - suppliers or other participants of the supply chain must have demonstrated a strong sustainability standing, have carried out a third party audit in order to ensure Environmental Management Systems and Quality Management Systems are robust and of high standard for the safeguard of our environment; need to have demonstrated a strategy towards achieving Net Zero by 2030. In order to demonstrate this, suppliers or intermediaries can have completed or be working towards the following measures:

1) carbon offsetting part of their operations;

2) have become carbon neutral;

3) have committed to Net Zero by 2030 within their business strategy;

4) have taken action over the past year to reduce their carbon emissions through addressing impact hotspots across their business operations;

5 ) have eco-friendly production processes: depending on the nature of the supplies the vendor is producing, they will have ensured they have acquired the right certifications 
to ensure no harmful chemicals are used throughout the production process, waste is properly disposed of and reduction in resource use implemented where possible;

- undertake initiatives to promote greater environmental responsibility.

Major fashion brands have already announced their determination to stop using plastic, minimize pollution and take more care about the environment. Hugely supported by the celebrities, Pangaia fashion brand is gaining more and more popularity on the world fashion market. The name of the company is built from words - Pan (all inclusive) and Gaia (mother earth).

Pangaia is a minimalist ethical brand launched in 2018 which focuses on solving environmental issues and «is committed to a zero-waste circular system that works with upcycled or recycled materials» [20]. One of the founders of the company is Miroslava Duma, who is a well-known proponent of sustainable fashion.

The main characteristic of the company's business model is their adherence to Direct-to-consumer (D2C) e-commerce. «D2C e-commerce is a term for an e-commerce strategy where traditional $\mathrm{B} 2 \mathrm{~B}$ businesses start selling directly to end-consumers via an e-commerce site» [21]. It means that Pangaia sells directly to their customers on their website [22].

There are numerous advantages of this D2C, the first being cutting out the middleman. It also gives a better control over the company's reputation and puts the company into direct contact with the end-consumer. Thus, consumers have stronger bonds with the company and increased interaction. The revenue comes not only from the direct sales, but also from «B2B textile sales, material materials licensing and brand partnerships for materials $R \& D$ » [23].
This hybrid business model is of interest to major fashion experts, such as Carmen Busquets and Jaden Smith, who decided to invest into the brand.

The fashion brand's team is described as fluid and hugely adaptable to the company's needs. Full-time staff numbers 94 people. There are also out-of-house collaborators, as well as researchers.

Pangaia fashion brand stands out on the fashion market in all manner of different ways being «a direct-to-consumer materials science company bringing breakthrough textile innovations and patents into the world through everyday lifestyle products» [24]. «Sustainability is kept on all levels of the company, the final product being «sustainable, essential-based apparel» [24]. Company tries to avoid overproduction and at the same reduce the footprint by having limited items in stock and taking pre-orders.

This is a material science company with its own research and development facility comprising the scientists, technologies and designers. The source of the clothing material is «bio-based or recycled fibers, then dyed from plants and coated with antibacterial peppermint to reduce washing» [25].

The philosophy of the brand can be described as «high-tech naturalism» [26]. In the interview to Vogue Parkes claims that «making materials out of anything - from bananas, to coffee, pineapples, grapes and apples - this is the stuff we're really excited about». She also adds that: «We want to use up waste produce wherever it appears in nature. We don't want the same thing to happen with cotton, which has been over-farmed and overproduced... we always want to stay in the realm of regenerative agriculture and variation, instead of a single solution».

\section{Business Model Canvas}

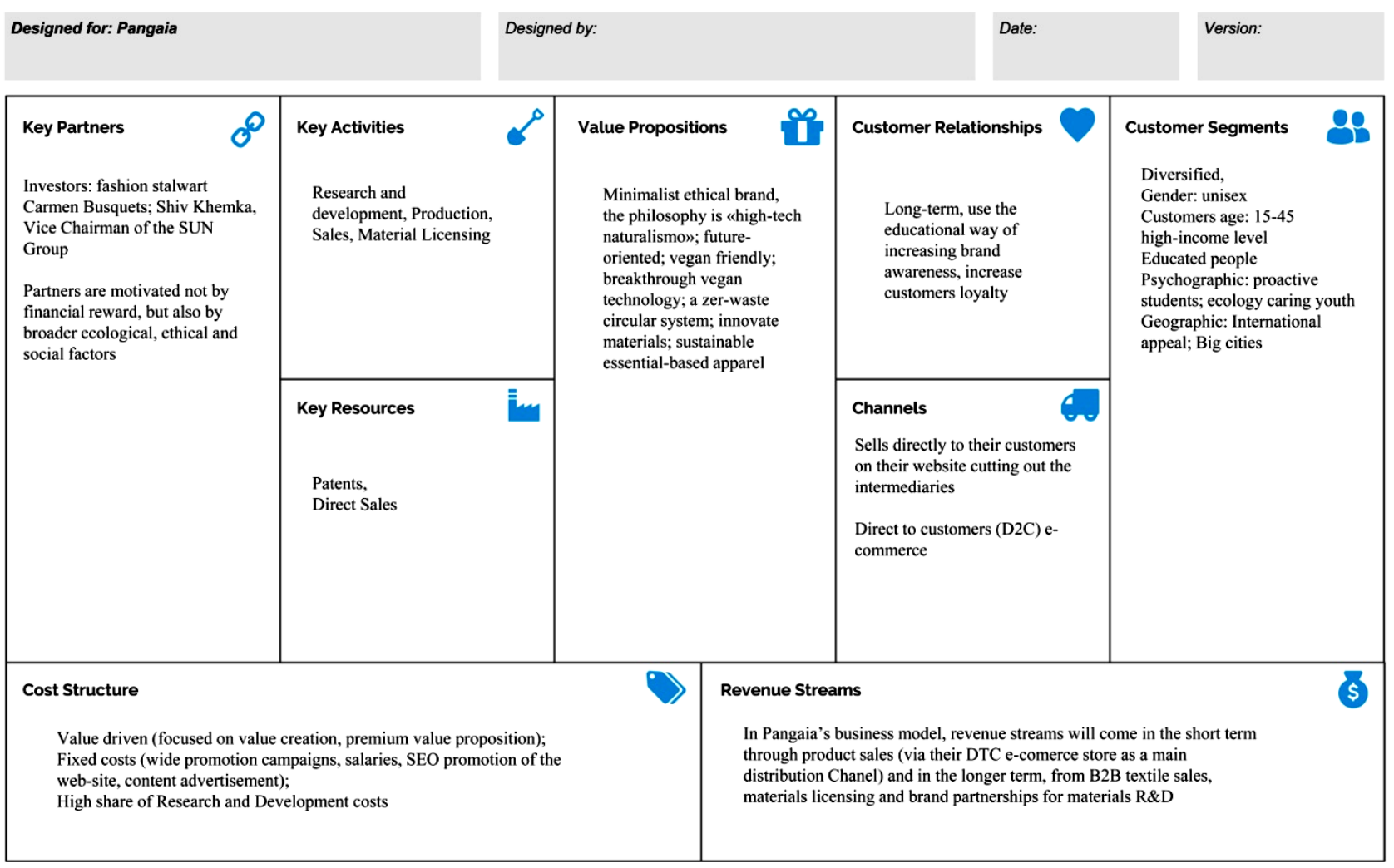

Fig. 1. Business model canvas for Pangaia brand (developed by the authors) 
As Pangaia unites the experts from around the world. Maria Srivastava, the brand's chief impact and communications officer states that «We're very future-thinking; our philosophy is to have as many people as possible join our journey» [27].

Pangaia is rated «Good» in terms of its impact on the environment [28].

Every technology applied by the company is carefully devised so that it can be instrumental in solving environmental issues.

Every environmental initiative will be studied below in a more detailed way

Pangaia brand business model corresponds to the $1^{\text {st }}$ sustainability criteria: implementing two or more of the CDG's $(6,11,13,14,15)$, their climate action pillars outline how to protect biodiversity by minimizing our environmental footprint. Beyond this, Pangaia is proud to have created two funds that support this cause. Through the Tree Fund planting they protecting and restoring trees with every product purchased. The SeaTrees project is restoring and protecting 26 hectares of degraded mangrove forest in the West Papua region of Indonesia. Here, local villagers are employed to plant a diverse mix of mangrove species, creating jobs, healthy ecosystems and habitats. The region's current mangrove estuaries are $75 \%$ deforested, which is why restoration is so important. This helps prevent damage caused by hurricanes and tsunamis.

Pangaia brand business model corresponds to the $2^{\text {nd }}$ sustainability criteria: the usage of sustainable fabriques or other sustainable parts of apparel. Inspired by the natural diversity in our ecosystems, they pioneer and use materials that consider the delicate balance between sustainability, functionality and purpose.

Interestingly enough, all the items produced by Pangaia are unisex. As for materials used, they are seaweed fiber (biodegradable seaweed); organic cotton (cotton from natural seeds); recycled materials (post-consumer textiles and recycled plastic waste); FLWRDWN (alternative to duck and goose gown); compostable packaging [28].

One of the main characteristics of the company is that it is vegan friendly, which was achieved after having spent 10 years on developing a breakthrough vegan technology, PANGAIA flowerdown. Moreover, «nothing is made with the skins, hair or feathers of animals, including fur, leather, wool, and silk. All fabrics are either plantbased or lab-grown» [29]. One of the company's aims is to build awareness «awareness for the vegan brands and their product offering and for this sector of the fashion industry to grow» [29].

Analyze of the sustainable business model let's compare the Advantages and disadvantages of having one (Table 2).

Fashion businesses are resorting to green ways more and more extensively. The innovative business model of the Pangaia brand can definitely be described as a sustainable one with a focus on highest quality, ethical standards and latest innovations. Pangaia is a minimalist ethical brand launched in 2018 which focuses on solving environmental issues and uses a zero-waste circular system that works with upcycled or recycled materials. The main characteristic of the company's business model is their adherence to Direct-to-consumer (D2C) e-commerce, which means that Pangaia sells directly to their customers on their website.
Advantages and disadvantages of having a sustainable business model

\begin{tabular}{|c|c|}
\hline Advantages & Disadvantages \\
\hline $\begin{array}{l}\text { Solid Business Opportunities - if you } \\
\text { have a product or service in the } \\
\text { energy, clean tech or green tech } \\
\text { sectors, or are dealing with every- } \\
\text { day challenges people face and are } \\
\text { competitive in your product/service, } \\
\text { you are in a good place }\end{array}$ & $\begin{array}{l}\text { Keeping } U_{p}-\text { since green business } \\
\text { is here to stay, keeping ahead of the } \\
\text { competition in new green technologies } \\
\text { and strategies can be quite challeng- } \\
\text { ing at times }\end{array}$ \\
\hline $\begin{array}{l}\text { Marketability Factor-since the media } \\
\text { is still praising going green, busi- } \\
\text { nesses can definitely find unique ways } \\
\text { to use this one. Just do not claim } \\
\text { you are greener than you really are }\end{array}$ & $\begin{array}{l}\text { Complexity of the Business Model-it's } \\
\text { hard enough to focus on one bottom } \\
\text { line: profits. True green businesses } \\
\text { not only focus on being profitable, } \\
\text { they also take responsibility for the } \\
\text { impact their business has on people } \\
\text { and the planet (known as the triple- } \\
\text { bottom-line or the three p's) }\end{array}$ \\
\hline $\begin{array}{l}\text { Easier to Compete - as long as your } \\
\text { product is just as good as or bet- } \\
\text { ter than non-green alternatives out } \\
\text { there you're in good shape. Even if } \\
\text { you cannot compete on price, there } \\
\text { are solid strategies to position your } \\
\text { product/service to be quite desirable }\end{array}$ & $\begin{array}{l}\text { Juggling Hats - most green business } \\
\text { owners are traditional business people } \\
\text { or environmentalists, but rarely both. } \\
\text { To thrive as a green business owner, } \\
\text { you must be great at both! }\end{array}$ \\
\hline $\begin{array}{l}\text { Strong Feel Good Component - if } \\
\text { your product/service really makes } \\
\text { a difference for the planet and society, } \\
\text { you can certainly leverage this in } \\
\text { your branding and marketing. People } \\
\text { like knowing what they purchase is } \\
\text { going to help more than just them- } \\
\text { selves, with everything else being } \\
\text { relatively equal }\end{array}$ & $\begin{array}{l}\text { Play By the Same Rules... For Now- } \\
\text { many green business owners expect } \\
\text { people will come flocking to their pro- } \\
\text { duct or service because of how green } \\
\text { it is. They usually are in for a rude } \\
\text { awakening. If it does not compete on } \\
\text { the traditional business components of: } \\
\text { functionality, quality, fashion, and/or } \\
\text { price it will not succeed. Guaranteed }\end{array}$ \\
\hline $\begin{array}{l}\text { More Stable - businesses that build } \\
\text { not only a profitable business but } \\
\text { one that integrates the social and } \\
\text { environmental components that sur- } \\
\text { round it, usually do better than their } \\
\text { "non-green» competitors }\end{array}$ & - \\
\hline
\end{tabular}

The key findings and analysis of its values and corporate culture signify that this is a material science company with its own research and development facility comprising the scientists, technologies and designers. The findings also highlight the organizational structure of the company, people working there and the main environmental initiatives. Pangaia fashion brand stands out on the fashion market in all manner of different ways. The philosophy of the brand can be described as «high-tech naturalism». Company tries to avoid overproduction and at the same reduce the footprint by having limited items in stock and taking pre-orders.

\section{Conclusions}

Authors have achieved the aim of the specificized key aspects of sustainability elements within business models in the fashion industry. The business model Canvas has been compiled for fashion business which is following the sustainability requirements that afford to make a list of compulsory minimal bundle of sustainable components within business model, which should indicate for potential customers that company indeed has the sustainable business model. This company portrait will help for distinguishing the «real» sustainable brands from disguised. The sustainable business model canvas is provided as an 
empirical research result, which used the Pangaia brand as the most successful sustainable start-up within fashion industry. The brand as an sample was picked up from 20 sustainable fashion brands using two different criteria the first is economic (growth of employees, revenue growth, operational activities proceeding at least during two years, CIS code - producing clothes and Wholesale/Retail sale of clothing activities); the second is quantity of sustainable development principles, which this brand has implemented into practise. The brand Pangaia met the majority of the criteria so was picked up as an most suitable for making the Canvas template. The results can be used for further research but external and internal environment factors should be considered to clear understanding the success formula of the Pangaia depends not only on combination and interaction of the business components. The corelation existence between factors and results which is not inspected whilst working on this article is interesting for further research. The case of Pangaia is extremely interesting because of Covid crisis haven't destroyed the company on introductory life cycle stage, which was established right before the start of Pandemic, so the business model considering this should be studied in more précised way.

\section{References}

1. Thorisdottir, T. S., Johannsdottir, L. (2019). Sustainability within Fashion Business Models: A Systematic Literature Review. Sustainability, 11 (8), 2233. doi: http://doi.org/10.3390/ su11082233

2. Blowfield, M., Murray, A. (2008). Corporate Responsibility. Oxford: Oxford University Press, 413

3. Claudio, L. (2007). Waste Couture: Environmental Impact of the Clothing Industry. Environmental Health Perspectives, 115 (9), 448-454. doi: http://doi.org/10.1289/ehp.115-a449

4. De Brito, M. P., Carbone, V., Blanquart, C. M. (2008). Towards a sustainable fashion retail supply chain in Europe: Organisation and performance. International Journal of Production Economics, 114 (2), 534-553. doi: http://doi.org/10.1016/j.ijpe.2007.06.012

5. Wirtz Bernd, W. (2011). Business Model Management. DesignInstruments-Success Factors. Gabler Verlag. Springer Fachmedien Wiesbaden GmbH, 342

6. Slávik, Š., Bednár, R. (2014). Analysis of Business Models. Journal of Competitiveness, 6 (4), 19-40. doi: http://doi.org/10.7441/ joc.2014.04.02

7. Linder, J., Sharla, C. (2000). Changing Business Models: Surveying the Landscape. Available at: https://www.researchgate net/publication/243769365_Changing_Business_Models_Surveying_the_Landscape

8. Weill Peter \& Vitale Micahle. (2001). Place to Space: Migrating to eBusiness Models. Boston: Harvard Business School Press. Available at: https://hbswk.hbs.edu/archive/place-to-spacemigrating-ebusiness-models-making-clicks-become-bricks

9. Hedman, J., Kalling, T. (2003). The business model concept: theoretical underpinnings and empirical illustrations. European Journal of Information Systems, 12 (1), 49-59. doi: http://doi.org/ 10.1057/palgrave.ejis.3000446

10. Osterwalder, A., Yves, P. (2010). Business Model Generation: A Handbook for Visionaries, Game Changers, and Challengers. Willowbrook, IL: Audio-Tech Business Book Summaries.

11. Mark, J., Christensen, C., Henning, K. (2008). Reinventing Your Business Model. Harvard Business Reviewe, 87 (12), 52-60. Available at: https://www.researchgate.net/publication/281537631 Reinventing Your_Business Model

12. Rappa, M. (2006). Business Models on the Web. Available at: http://home.ku.edu.tr/ daksen/mgis410/materials/Business_ Models on the Web.pdf

13. Christian, N., Lund, M. (2018). Building scalable business models MIT Sloan Management Reviewe, 59, 65-69. Available at: https:// dun-net.dk/media/125194/bm-scalability-wp.pdf
14. Rothaermel, F. T. (2019). Strategic Management. New York: McGraw-Hill Education, 555. Available at: https:/ /www.worldcat.org/title/strategic-management/oclc/1007507152

15. Gaffié, A. (2019). Pangaia Is The Sustainable Fashion Brand Taking Over Instagram. Available at: https://www.lofficielsingapore.com/fashion/pangia-life-size-fashion

16. Talonen, T., Hakkarainen, K. (2014). Elements of Sustainable Business Models. International Journal of Innovation Science, 6 (1), 43-54. doi: http://doi.org/10.1260/1757-2223.6.1.43

17. Lüdeke-Freund, F. (2014). Working definitions of «Sustainable business model» \& «Business model for sustainability». Available at: https://sustainablebusinessmodel.org/2014/06/09/ working-definitions-of-sustainable-business-model-business-model-for-sustainability/

18. The Sustainable Development Goals. Official United Nations web-site. Available at: https://www.un.org/sustainabledevelopment/news/communications-material/

19. WCED Our Common Future. Chapter 2: Towards Sustainable Development-A/42/427 Annex, Chapter 2-UN Documents: Gathering a body of global agreements. Available at: http://www. un-documents.net/ocf-02.htm

20. Cheng, Z. (2018). Pharrell's favorite ethical brand has launched globally. Available at: https://hypebae.com/2018/12/sustainablebrand-pangaia-lookbook

21. D2C e-commerce. Available at: https://www.sana-commerce. com/e-commerce-terms/what-is-d2c-e-commerce/

22. Pangaia official web-site. Available at: https://thepangaia.com/ pages/impact-our-vision

23. Roberts-Islam, B. (2019). This Startup Is Reshaping What It Means To Be A Sustainable Fashion Brand, From Materials Through To Products. Available at: https://www.forbes.com/ sites/brookerobertsislam/2019/12/05/this-startup-is-reshapingwhat-it-means-to-be-a-sustainable-fashion-brand-from-materialsthrough-to-products/?sh=42cd25a5732f

24. The PANGAIA. Reikan. Available at: https://reikancreations. com/the-pangaia

25. Pangaia is the material science-focused brand that is redefining sustainable loungewear (2021). Available at: https://vogue.sg/ pangaia-sustainable-loungewear/

26. Conlon, S. (2020). Pangaia, Young Hollywood's Favourite Loungewear Label, Comes With Superlative Sustainable Credentials. Available at: https://www.vogue.co.uk/fashion/article/pangaiasustainable-loungewear-brand

27. Manoff, J. (2019). Fashion brands are abandoning traditional ors charts in favor of 'fluid' teams. Available at: https://www.glossy. co/fashion/fashion-brands-are-abandoning-traditional-org-charts/

28. Good on you. PANGAIA. Available at: https://directory.goodonyou. eco/brand/pangaia\#

29. PANGAIA: «We Spent 10 years Developing a Breakthrough Vegan Technology» (2019). Vegconomist. Available at: https:// vegconomist.com/interviews/pangaia-we-spent-10-years-developing-a-breakthrough-vegan-technology/

Olena Vynogradova, Doctor of Economic Sciences, Professor, Head of Department of Marketing, State University of Telecommunications, Kyiv, Ukraine, e-mail: evoy@ukr.net, ORCID: https:// orcid.org/0000-0002-7250-5089

Nadiia Pysar, Doctor of Economic Sciences, Professor, Department of Marketing, State University of Telecommunications, Kyiv, Ukraine, e-mail: diserdiser72@gmail.com, ORCID: http://orcid.org/ 0000-0003-2656-7323

Nina Drokina, Doctor of Economic Sciences, Associate Professor, Department of Marketing, State University of Telecommunications, Kyiv, Ukraine, e-mail:drokina.nina@gmail.com, ORCID: https://orcid.org/ 0000-0002-8348-1203

Olga Lytoynova, PhD, Associate Professor, Department of Marketing, State University of Telecommunications, Kyiv, Ukraine, e-mail: o.voropaieva@gmail.com, ORCID: https://orcid.org/0000-00023291-3651

Iryna Sovershenna, PhD, Associate Professor, Department of Marketing, State University of Telecommunications, Kyiz, Ukraine, e-mail: iras2007@ukr.net,ORCID: https://orcid.org/0000-0001-5592-9130 